\title{
ARTICLE \\ Achmea versus the Rule of Law: CJEU's Dogmatic Dismissal of Investors' Rights in Backsliding Member States of the European Union
}

\author{
Dimitry Vladimirovich Kochenov ${ }^{1}$ (D) Nikos Lavranos $^{2}$
}

Accepted: 17 March 2021 / Published online: 29 March 2021

(c) The Author(s) 2021

\begin{abstract}
We demonstrate that the CJEU's Achmea judgment has resulted in significantly more damage beyond the termination of intra-EU BITs. It made the application of EU law difficult, if not impossible. Indeed, it has opened the floodgate to deficient judicial protection in the face of structural backsliding of the rule of law in some EU Member States. While the motives of the CJEU and by extension the European Commission to safeguard their ultimate control over the internal market by exclusively relying on the preliminary ruling system of integrated European judiciary may be understandable, they cannot serve as a credible justification for the longterm consequences of disempowering investors in the name of an ideological stance regarding EU judiciary, which cannot work in the backsliding Member States, where the 'integration of the EU's judiciary' could stand for the absence of independent adjudication. Consequently, the Achmea judgment and post-Achmea developments such as the recently signed Termination Agreement to terminate the intra-EU BITs have been leading to significant-possibly irreparable in the short- to mediumterm-lowering of the procedural and substantive protection standards for European investors in times when they are in need of more rather than less protection.
\end{abstract}

Keywords Achmea $\cdot$ Rule of law $\cdot$ Backsliding $\cdot$ EU values $\cdot$ CJEU $\cdot$ Judicial protection

\footnotetext{
This work has been prepared in the auspices of the EU's Horizon 2020 Research and Innovation Programme as part of RECONNECT project under the grant agreement No. 770142. The assistance and comments of numerous colleagues, especially Petra Bárd and Daniel Dozsa, anonymous reviewers and of Emma Schulte is kindly acknowledged.
}

Dimitry Vladimirovich Kochenov

d.kochenov@rug.nl

1 Head of the Rule of Law Working Group, CEU Democracy Institute and Professor, University of Groningen (the Netherlands) and Central European University, Budapest, Hungary

2 Secretary General of EFILA, Founder of NL-Investmentconsulting, Guest Professor, Brussels Diplomatic Academy, Free University of Brussels, Ixelles, Belgium 


\section{Introduction}

The democratic and rule of law backsliding in several Member States is on the rise. ${ }^{1}$ So far, it has found no effective opposition on the ground in the politically captured Member States. ${ }^{2}$ At the supranational level, the response from EU institutions has been lethargic. ${ }^{3}$ The Court of Justice of the EU (CJEU) stood out in this context, as it managed to mobilise the key values on which the Union and the Member States are built to embark on the articulation of a comprehensive, coherent, and effective system of rule of law protection at all the levels of governance in Europe, using the values of EU law and the alliance between the national and supranational courts as a means. ${ }^{4}$ The Court is thus in the midst of the "quest for national, supranational and transnational justice'. ${ }^{5}$ It uses the values - with a particular emphasis on judicial independence and irremovability as its core point of departure-as a base to stretch its own jurisdiction to shape a clear substantive vertically-integrated understanding of judicial independence in Europe as an indispensable part of the rule of law and a crucial factor behind the preservation of the unity in the multi-layered European legal system. ${ }^{6}$ Following the editors of the Common Market Law Review, it, indeed, seems true in the current context that 'in the face of adversity, EU law is capable of relying on its own system of principles and values. ${ }^{7}$

All the progress described above notwithstanding, the EU is ages away from a coherent and effective system of rule of law adherence and enforcement, as the judicial victories have a hard time translating into tangible improvements on the ground: the Commission is by now accustomed to 'losing through winning', as the situation on the ground in the backsliding states only deteriorates following the cases the Commission would win against those states (Scheppele et al. 2020). To complicate the story even further, the CJEU behaves as if it was not bound by its own rule of law case-law, giving rise to worries about the emergence of double standards in Europe as far as the basic standards of judicial independence and irremovability are concerned (Kochenov and Butler 2020). One can thus be mildly optimistic concerning the EU's turn to a more serious treatment of the rule of law-but this optimism needs a lot of context and a lot of caution.

There is one more outlier in the current story, which is capable, we argue, to significantly undermine the success of the CJEU's 'values project' and which is the

\footnotetext{
1 See Pech and Scheppele 2017, Cf. e.g. Sadurski 2019; Smith 2019, p. 563. For the analyses of the ongoing academic debate, see, Mader 2019, Bonelli 2017.

2 See Blokker 2019; Adamski 2019; Scheppele 2017, p. 35.

3 Scheppele, Kochenov and Grabowska-Moroz 2020, Cf. e.g. the JCMS special Issue edited by Kochenov, Magen and Pech 2016; Schout and Luining 2018.

4 Pech and Kochenov 2020; Koncewicz 2020; Kochenov and Bárd 2019.

5 Lenaerts 2019; But see, from a number of different angles: Kochenov, de Búrca and Williams 2015. This understanding goes hand in hand with the gradual articulation of the best practices in the field of the rule of law in the EU: Grabowska-Moroz 2020.

${ }^{6}$ Cf. Kochenov 2020.

7 Editorial Comments (2018) EU Law between Common Values and Collective Feelings. CMLRev $55: 1329$
} 
focus of this paper. This outlier is the Achmea case-law ${ }^{8}$ and the successful attempts of the Court and the Commission to annihilate the bilateral investment treaties (BITs) between the Member States, coupled with all the guarantees of justice and rights protection that come with it. While the CJEU's position is significantly reinforced as a result, the system of effective remedies available to safeguard justice and rights suffers a huge blow, especially in the backsliding Member States, where local courts in several Member States have a hard time to meet the independence threshold $^{9}$ and no other tribunals are available as a result of the CJEU's and the Commission's crusade against intra-EU BITs with their arbitral tribunals. Under the pretext of reinforcing EU law and upholding dialogue between national and supranational courts, the Court and the Commission have thus significantly undermined judicial protection in Europe. Achmea can therefore be characterised as a self-serving step back along the path of reinforcing judicial protection, which benefits no one else but the Court of Justice. Below we defend this position and give clear examples of Achmea's devastating effects.

\section{Achmea and the Termination Agreement: Charting the Step Back}

Indeed, at first glance the case of Achmea consistently tells the same story as all the recent case-law on the rule of law: Article 2 of the Treaty on European Union (TEU) in combination with the idea of a unified European judiciary as expressed in Article 19(1) TEU functioning with the help of the preliminary ruling procedure and the essential principle of mutual trust is absolutely fundamental for the proper functioning of the European legal order and the full protection of its values, principles as well as rights (Rizcallah and Davio 2020; Pech and Platon 2018a, b; Adam and Van Elsuwege 2018). This context is clear-cut and convincing, but the implications which the Court of Justice draws from it are probably less so.

In fact, the case undermines judicial protection in Europe and has a devastating effect for the level of judicial protection in Europe, especially the protection of the rights of investors, which used to be covered by intra-EU BITs between the Member States, as well as the implications for the successful operation of the internal market (Nagy 2018; Gáspár-Szilágyi 2018; Sadowski 2018). The reasons essentially come down to one: the Court gives strong preference to the forceful proclamation of mutual trust in the context when all the logic above is deployed in a matter

\footnotetext{
${ }^{8}$ CJEU, Slovak Republic v. Achmea [2018] ECLI:EU:C:2018:158, paras. 33-37.

9 See e.g., the 2020 Justice Scoreboard of the EU, https://ec.europa.eu/info/sites/info/files/justice_score board_2020_en.pdf.

As far as Polish courts are concerned, the Amsterdam court clearly questions the independence of Polish courts, and consequently refused to extradite criminal suspects to Poland, see: https://www.politico. eu/article/dutch-netherlands-courts-to-stop-extraditing-poland-suspects/. See already a very early warning by the Statement of the European Network of Councils of Judiciary concerning the judicial reforms in Poland, 26 April 2017, https://www.encj.eu/node/461. Cf. Sadurski 2019.

As regards Hungary, see Amnesty International Report, Fearing the Unknown, How rising control is undermining judicial independence in Hungary, April 2020, https:/www.amnesty.eu/wp-content/uploa ds/2020/04/FINAL_Fearing-the-Unknown_report_Amnesty-Hungary_E1.pdf. Cf. Pech and Scheppele 2017.
} 
distrustful of international law rights guarantees and is oblivious of the significant substantive problems apparent in the sphere of fundamental rights protection as well as the rule of law and the independence of the judiciary throughout the Union, in particular in Poland and Hungary. Having acquired substantive jurisdiction to look into the guarantees of judicial independence, ${ }^{10}$ it extended the scope of the rule of law jurisprudence to include strict irremovability standards applicable to judges. ${ }^{11}$ Substantive guarantees are policed ${ }^{12}$ with a rich palette of interim relief measures, which include ex ante restitutions in institutional structures, ${ }^{13}$ by EU law. ${ }^{14}$ Preliminary rulings from the judges fighting for their own independence play a crucial role in these developments. ${ }^{15}$ All in all, however, these developments-although significantly reinforcing the position of the Court of Justice-failed to protect the judiciaries in Hungary and Poland. ${ }^{16}$

The Pyrrhic victories in the context of the fight for the rule of law in Poland and Hungary came to be reinforced in Achmea. The Court ruled that Article 19(1) TEU and Articles 344 and 267 of the Treaty on the Functioning of the European Union (TFEU) preclude reciprocal investment protection via arbitral tribunals established under the BIT concluded between the Netherlands and the Slovak Republic. As a consequence thereof, Member States and investors are pushed to rely on the local courts of the Member States instead, Article 19(1) TEU thus emerges in quite an interesting light (Fanou 2019, at p. 322 et seq). Autonomy of EU law is undermined even when there is the slightest risk of any court or tribunal not falling within the scope of this provision applying EU law. ${ }^{17}$ Even more, the very existence of any alternatives to the courts falling within 'within the judicial system of the EU' (Andenæs and Contartese 2019, at p. 174) — the scope of Article 19(1) TEUalready, by definition is viewed by the Court of Justice as potentially undermining mutual trust between the Member States. ${ }^{18}$

The protection of the proclamation of mutual trust and the perceived integrity of EU law enjoys priority over the sober analysis of the situation with the rule of law and judicial independence on the ground and de facto-but also de jure, given the level of protection of investors' rights under EU law-move the idea of the

\footnotetext{
${ }^{10}$ Case C-64/16 Associação sindical dos juízes portugueses [2018] ECLI:EU:C:2018:117; Pech and Platon 2018a, b; Adam and Van Elsuwege 2018.

11 E.g. C-619/18, Commission v Poland (Independence of the Supreme Court); Judgment of the Court (GC) in Case C-192/18, Commission v Poland (Independence of the ordinary courts).

12 Case C-791/19 R Commission v Poland (Independence of the Disciplinary Chamber of the Supreme Court).

13 Order of the Court (GC) in Case C-619/18 R, Commission v. Poland (Independence of the Supreme Court).

14 For a significant break-through in interim relief, see, most importantly, Order of the Court (GC) in Case C-441/17 R, Commission v. Poland (Białowieża forest). Cf. Wennerås 2019.

15 Joined Cases C-585/18, C-624/18 et C-625/18, A. K. e.a. (Independence of the disciplinary chamber of the Supreme Court).

16 Cf. Scheppele, Kochenov and Grabowska-Moroz 2020. (with the literature and case-law cited therein).

17 Cf. Andenæs and Contartese 2019, at p. 170.

18 See Lavranos 2010, on the concept of 'hypothetical incompatibilities' between the availability of international courts and tribunals and the exclusive jurisdiction of the CJEU.
} 
protection of rights to the back seat. Implications of the case in the context of the rule of law are truly dramatic: deterioration of the rule of law in some Member States, which the EU does not have the tools to effectively counter, when combined with the outlawing of the BITs results in a simple cancellation of the whole idea of judicial protection in the places where it is needed the most. Moreover, as pointed out by AG Wathelet in his Opinion in Achmea, this move contradicts the pre-accession efforts of the Commission. ${ }^{19}$ The pre-accession Europe Agreements focused precisely on encouraging the Central and Eastern European states to conclude BITs with the then EU Member States in order to prepare them for the accession to the EU. ${ }^{20}$ Indeed, as AG Wathelet concluded in his Opinion and as was convincingly explained before that by one of his former referendaires Paschalis Paschalidis, it would have been possible to reconcile intra-EU BIT arbitration with the preliminary ruling system. ${ }^{21}$ Accordingly, from a strictly legal point of view, there was no need at all for the CJEU to declare intra-EU arbitration incompatible with EU law. However, suddenly these very same BITs are now mauvais ton in the problematic postAchmea world.

The outcomes of Achmea are thus far-reaching indeed: scholars speak about an outright war waged by the Court of Justice against the BITs and arbitral tribunals (Uzelac 2019). While it may be understandable from the point of view of the Court to protect its turf and its authority as being the highest judge as far as the interpretation and application if EU law is concerned, this attitude at the same time undermines the coherence of international law. ${ }^{22}$ In this context, it is important to recall that in contrast to the BIT that was at issue in Achmea, most intra-EU BITs do not even list EU law as one of the possible sources of applicable law for arbitral tribunals. Therefore, the risk that arbitral tribunals might systematically misapply or misinterpret EU law is very low indeed.

19 AG Wathelet, Opinion in Achmea, para. 40.

${ }^{20}$ See in particular, Micula et al. v. Romania, ICSID Case No. ARB/05/20, Award, 11 December 2013, paras. 320 et seq (online) available at: https:/www.italaw.com/sites/default/files/case-documents/itala w3036.pdf.

See, for example, the first indent of Article 72(2) of the Europe Agreement establishing an association between the European Communities and their Member States, of the one part, and the Republic of Hungary, of the other part, signed in Brussels on 16 December 1991 (OJ 1993 L 347, p. 2); the first indent of Article 73(2) of the Europe Agreement establishing an association between the European Communities and their Member States, of the one part, and the Republic of Poland, of the other part, signed in Brussels on 16 December 1991 (OJ 1993 L 348, p. 2); the second indent of Article 74(2) of the Europe Agreement establishing an association between the European Communities and their Member States, of the one part, and Romania, of the other part, signed in Brussels on 1 February 1993 (OJ 1994 L 357, p. 2); the second indent of Article 74(2) of the Europe Agreement establishing an association between the European Communities and their Member States, of the one part, and the Slovak Republic, of the other part, signed in Luxembourg on 4 October 1993 (OJ 1994 L 359, p. 2); and the second indent of Article 85(2) of the Stabilisation and Association Agreement between the European Communities and their Member States, of the one part, and the Republic of Croatia, of the other part, signed in Luxembourg on 29 October 2001 (OJ 2005 L 26, p. 3).

21 Paschalidis 2017.

22 Đajić 2018. Cf. Koutrakos 2019. 
Despite that, should the efforts of the Court be successful-as it appears to be the case, this would render non-existent the protection of investors' rights which are not guaranteed by EU law in all the jurisdictions as well as all the other (fundamental) rights in the backsliding Member States. This is not only because of the problems with the rule of law in some of the backsliding Member States, whose hijacked courts are now the only guardians of the rule of law remaining, as we will discuss further in some more detail.

The problem also relates to the substance of EU law rights afforded to investors, which does not at all overlap with what is offered under the BITs, as the arbitral tribunal in Achmea compellingly demonstrated. ${ }^{23}$ This overwhelmingly prevailing view has so far only been disputed by one dissenting opinion of Marcelo Kohen. ${ }^{24}$

Most ironically - and in line with the BITs' traditional role of promoting the rule of law - to which we will turn to in a brief while, the standards they establish are not in any way atypical or particularly high: they are similar, as Csongor István Nagy explains, to established standards of protection corresponding to 'the ones already part of the constitutional traditions of Western democracies' (Nagy 2018, at p. 984). Indeed, this is also confirmed by the judgment of the German Federal Constitutional Court (Bundesverfassungsgericht) in 2016 regarding the sudden closure of nuclear power plants in Germany following the Fukushima disaster. The Bundesverfassungsgericht concluded that the expropriated owners of the nuclear power plants must be compensated by the German State due to the violation of their right to property as protected under Article 14 of the German Constitution. ${ }^{25}$ This case is essentially similar to the Vattenfall v. Germany ${ }^{26}$ case brought under the Energy Charter Treaty (ECT), which reportedly has been settled by Germany agreeing to pay 2,4 billion EUR in compensation in total of which Vattenfall will receive 1,6 billion EUR. ${ }^{27}$ Obviously, by paying such a huge amount, Germany indirectly admitted at the international law level that it violated the rights of Vattenfall under the ECT, thereby confirming the findings of the Bundesverfassungsgericht, which it reached for the domestic level.

\footnotetext{
23 PCA, Achmea v. Slovak Republic, PCA Case No. 2008-13, Award on Jurisdiction, Arbitrability and Suspension, 26 October 2010, paras. 245 et seq. (online) available at: https://pcacases.com/web/sendA ttach/775.

24 Theodoros Adamakopoulos v. Cyprus, ICSID Case No. ARB/15/4, Statement of Dissent of Prof. Marcelo G. Kohen, 3 February 2020. Kohen essentially considers it futile to compare BITs with EU law because they are different. He concludes in para. 31: "For the purposes of this concrete analysis, the crucial point, however, is that considering the protection in one case being better than in another rather shows that the subject-matters are the same. It is elementary that something cannot be better than something else if they are substantially different. One cannot compare apples with pears, even though both are fruits." https://www.italaw.com/sites/default/files/case-documents/italaw11239.pdf.

This rather circular argument, however, is not convincing and does not make it impossible to compare the substantive standards as other arbitral tribunals have repeatedly done so and indeed conclude that the BIT standards offer a higher level of protection than EU law and that the subject-matters are different.

25 BVerfG, Urteil des Ersten Senats vom 6. Dezember 2016 - 1 BvR 2821/11, Rn. 1-407, http://www. bverfg.de/e/rs20161206_1bvr282111.html.

26 Vattenfall v. Germany, ICSID Case No. ARB/09/6.

27 Sanderson 2021.
} 
There should be no problem getting rid of these standards then, replacing them with EU law. The trouble is that EU law, in substance and beyond the rhetoric of mutual trust, is not, objectively, at that level yet. ${ }^{28}$ The arbitral tribunal had no difficulty to find precisely this in Achmea. ${ }^{29}$ Besides, and equally problematic, one should not forget the antagonistic zero sum world of global constitutionalism the Court is richly painting in Achmea. The obvious investment protection perspective has not found its way into the judgement of the Court at all, while it is unquestionable, to quote Emily Sipiorski, that.

'Through the lens of global constitutionalism it could be argued that the arbitral tribunal was upholding fundamental rights and the rule of law from the perspective of the rights and protections of investors contained in investment agreements as protected by public international law' (Sipiorski 2019, at p 222).

The question thus remains what to do with all those rights - in backsliding Member States, but also in others-which are no more available, presumably, following the rejection of international arbitration by the Achmea Court? The introduction of the EU's own system of rights, which would come close to what has just been slashed, could make us wait a long time (Anderer 2010, at p. 881; Lavranos 2011). In the meanwhile-and moving beyond the rights per se-the effects of Achmea on the internal market could be quite drastic, since research shows that the BITs actually do matter, when investment decisions are taken (Mistelis 2020; Brower and Blanchard 2014). In fact, they definitely mean more than the Court's proclamations of trust backed by nothing but the deterioration of the rule of law landscape in a handful of jurisdictions.

Following Achmea, the intra-EU BITs had to go. On 15 January 2019, the Member States adopted a political Declaration stating their intention to terminate all their ca. 190 intra-EU BITs by 6 December 2019 and emphasising that there is no need for any additional protection of the investors in the EU, given the rights and freedoms offered by EU law. ${ }^{30}$ Moreover, the political Declaration contained the following far-reaching statements and commitments.

- First, the Member States declared that as a consequence of Achmea all arbitrations based on intra-EU BITs are-ab initio-incompatible with EU law and

\footnotetext{
28 Vattenfall v. Germany, ICSID Case No. ARB/09/6.

29 Achmea B.V. v. Slovak Republic, UNCITRAL, PCA Case No. 2008-13 (formerly Eureco B.V. v. Slovak Republic) (26 October 2010) Award of Jurisdiction, Arbitrability and Suspension, para. 262: 'Thus EU law does not provide substantive rights for investors that extend as far as those provided by the BIT. There are rights that may be asserted under the BIT that are not secured by EU law'.

30 Declaration of the Representatives of the Governments of the Member States on the legal consequences of the Achmea judgment on investment protection in the EU (15 January 2019) (online) available at: https://ec.europa.eu/info/sites/info/files/business_economy_euro/banking_and_finance/documents/ 190117-bilateral-investment-treaties_en.pdf. In addition, two other political Declarations were adopted: one by 5 Member States and a separate one by Hungary, which did not agree with the majority's view that the Achmea judgment should also be applied to intra-EU ECT disputes.
} 
thus all pending and future disputes must be terminated or must be considered impossible.

- Second, the Member States stated in the Declaration that they would inform all courts-whether based within or outside the EU- that no intra-EU BIT awards may be recognized or enforced any longer.

- Third, the Declaration also stated that Member States will direct any companies, which they control, to withdraw any ongoing disputes against other Member States. This seemingly is directed to apply to the Vattenfall v. Germany case since Vattenfall is owned by the Swedish State, which would mean that the Swedish Government would have to direct the Board of Directors of Vattenfall to withdraw their on-going ECT dispute against Germany, whose award in the merits is expected any moment. Clearly, this would be an unprecedented political interference in the judicial process of an on-going arbitration.

In short, the Member States seized the Achmea judgment as an opportunity and justification to bring — once and for all—an end to all intra-EU BITs and any ongoing or future intra-EU BITs (and even intra-EU ECT) cases.

These political intentions were converted into a legally-binding text in the form of the so-called Termination Agreement, which on 5 May 2020 was signed by 23 Member States. ${ }^{31}$ For obvious reasons, the UK did not sign up to this Termination Agreement and neither did Finland, Sweden, Austria and Ireland. The Termination Agreement has entered into force since the end of August 2020 for most of the signatory EU Member States. ${ }^{32}$

The Termination Agreement essentially replicates the main intentions of the political Declaration referred above. Thus, all intra-EU BITs and all disputes based on them are declared incompatible with EU law and thus proclaimed moot. New intra-EU BIT arbitrations are declared not to be possible any longer. The most disturbing aspect of the Termination Agreement in the context of the elimination of previously guaranteed rights concerns the declared inapplicability of the sunset clauses contained in every intra-EU BIT (Stoppioni 2020). It is important to recall that the very purpose of sunset clauses (sometimes also referred to as survival clauses) is to guarantee that all investments, which were made prior to the termination of a BIT continue to be protected for significant period of time, typically ranging from 5,10 , 15 and up to 20 years. ${ }^{33}$ The function of the sunset clause is to protect the legal expectations of the investors who made their investments based on the protection

\footnotetext{
31 Agreement for the termination of Bilateral Investment Treaties between the Member States of the European Union, OJ L 169, 29.5.2020, p. 1-41<https://eur-lex.europa.eu/legal-content/EN/TXT/PDF/? uri $=$ CELEX:22020A0529(01)\&from $=E N>$.

32 See the database regarding the state of play of the Termination Agreement: < https://www.consilium. europa.eu/en/documents-publications/treaties-agreements/agreement/ $\mathrm{id}=2019049 \&$ DocLanguage $=$ en $>$.

33 For example, Article 13(3) of the Netherlands-Slovakia BIT states: 'In respect of investments made before the date of the termination of the present Agreement the foregoing Articles thereof shall continue to be effective for a further period of fifteen years from that date'.

Article 47 (3) ECT provides for an even longer sunset period of 20 years.
} 
offered by the existing investment treaties. Indeed, many investment treaties also cover investments made prior to the entry into force of the treaty. ${ }^{34}$

The reason why States have included sunset clauses in practically all their BITs is to protect the legal expectations of their investors when making their investments. Typically, foreign investments, in particular in the oil, gas and infrastructure sectors, are made with a long-term view, which often goes beyond the standard initial period of validity of a BIT of 10 or 15 years. In those circumstances, a termination of a BIT is always a possibility and without a sunset clause existing investments would be left completely unprotected. In other words, sunset clauses aim to ensure that investors of existing investments have a transitional period in which they can take the appropriate measures to accommodate to the situation after a BIT has been terminated. Sunset clauses also ensure that investors can still use the dispute settlement provisions in order to be able to obtain compensation in cases of (in) direct expropriation by the host State. Accordingly, investment claims can be successfully initiated even after the termination of the BIT. For example, in the Marco Gavazzi and Stefano Gavazzi v. Romania case, ${ }^{35}$ the investors initiated arbitration under the Italy-Romania BIT in 2012 after the treaty had already been terminated in 2010. In April 2019, a Dutch investor filed an ICSID claim against Tanzania six months after the termination of the Tanzania-Netherlands BIT. ${ }^{36}$

To protect investors' expectations in the face of a sudden termination of the BIT is thus the sole purpose of the sunset clauses. Consequently-and in contrast to the stated intention of the EU Member States in the Termination Agreement-the termination of a BIT itself clearly does not prevent the filing of claims, unless the Contracting Parties of the BIT have agreed to remove the sunset clause before terminating the BIT. ${ }^{37}$

The sunset clauses in the intra-EU BITs have not been removed and therefore are still fully applicable. Indeed, it is important to note that it is for each and every arbitral tribunal to decide whether or not it has jurisdiction. It is submitted that they will in all likelihood accept their jurisdiction, despite the risk that their awards may not be enforceable within the EU. ${ }^{38}$ Any other conclusion would run counter one of

\footnotetext{
${ }^{34}$ For example, Article 7 of the Netherlands-Bulgaria BIT signed in 1988 states: 'The present Agreement shall apply to investments which were made by investors of either Contracting Party in compliance with the legal regulations of the other Contracting Party in the territory of the latter as from January, 1, 1964'.

${ }^{35}$ Marco Gavazzi and Stefano Gavazzi v. Romania (ICSID Case No. ARB/12/25).

$<$ https://jusmundi.com/en/document/decision/en-blue-bank-international-trust-barbados-ltd-v-boliv arian-republic-of-venezuela-award-wednesday-26th-april-2017 > .

${ }^{36}$ Ayoub-Farid Michel Saab v. United Republic of Tanzania (ICSID Case No. ARB/19/8) < https://jusmu ndi.com/en/document/decision/en-ayoub-farid-michel-saab-v-united-republic-of-tanzania-tuesday-16thapril-2019>.

37 Reportedly, when Indonesia reached a mutual agreement with Argentina to terminate their BIT, they neutralized the sunset clause by mutual agreement before withdrawing from the BIT. This implies that the sunset clause will not operate for existing investments following termination. The Czech Republic has used the same approach earlier and removed its sunset clauses prior to the agreed termination of several BITs with fellow EU Member States.

38 Indeed, the Vattenfall arbitral tribunal explicitly underlined the point that any potential risk of nonenforceability of its award due to a possible incompatibility with EU law in the future is irrelevant for accepting its jurisdiction over the case. In para. 230, the tribunal simply concluded that: "The enforce-
} 
the most basic fundamental elements of the rule of law, namely, the prohibition to retroactively remove procedural and substantive rights granted by virtue of binding international treaties. Consequently, the Termination Agreement further exacerbates the devasting impact of the Achmea judgment by giving all Member States-including those which are backsliding on the rule of law front-a carte blanche to continue on this path. The situation arose, when the European Commission, the Member States and the CJEU are jointly contributing to this unfortunate outcome, which is far removed from the most basic legality guarantees.

The actions by the Member States, the Commission and the CJEU taken as a whole have-whether intentionally or not-resulted into watering down the rule of law in investment protection in Europe. While anarchical in nature, when approached from the vantage point of the rule of law, is also entirely oblivious of the problems experienced by investors, in particular, in the backsliding Member States. Clearly, there might not only be no EU law there, but also no courts meeting the basic criteria of the rule of law and independence established by the Court of Justice in the most recent case-law building on the potential of Article 19 TEU. Besides, the Court and the Termination Agreement fail to see that there are whole lists of rights protected by the current BITs, which have no parallels in EU law even in the cases where the latter functions as proclaimed, as the AG in Achmea also made clear. ${ }^{39}$

In the context where-regarding the backsliding of Member States at leastmutual trust and the rule of law alongside with other values are mere proclamations and the EU has no way to enforce them (Kochenov 2017, at p. 419) - the BITs and protection rights contained therein are thus brought on the altar of coherence of EU law for nothing. Most surprisingly, the very essence of the principle of autonomy of EU law seems to be approached by the Court in Achmea through the presumption of EU law's deeply antagonistic relationship with other legal orders. Panos Koutrakos rightly points out in this context that:

'The judgment in Achmea, therefore, put forward a richer and broader concept of autonomy than the previous case-law had suggested. Viewed from this angle, autonomy becomes, in essence, about conflict. The main features of the principle as they emerge in the judgement (the low threshold of tolerance for arbitration tribunals dealing with EU law issues, the broad language of the judgment, the purported need of domestic courts to have their EU law role protected in any theoretical set of circumstances) enable the Court to construe the relationship between EU law and international investment law as an antagonistic one.'(Koutrakos 2019, at p. 56)

He continues only to underline that it would be a mistake to see the conflict as the only paradigm of EU law's relationship with international investment law. Countless

\footnotetext{
Footnote 38 (continued)

ability of this decision is a separate matter which does not impinge upon the Tribunal's jurisdiction." Vattenfall v. Germany, ICSID Case No. ARB/12/12, Decision on the Achmea issue, 31 August 2018, https:// www.italaw.com/sites/default/files/case-documents/italaw9916.pdf.

39 Para. 180 of the Opinion.
} 
other, more fruitful and mutually enriching, modes of engagement are possible and have been underlined in the literature, as well as in AG Wathelet's Opinion in the case, entirely ignored by the bellicose Court. ${ }^{40}$

\section{The rights lost: recent examples}

The following two recent examples of investment disputes, which tellingly involved Hungary as Respondent, illustrate how BITs and international arbitration provide an effective-indeed the only-tool for investors to protect their rights, while at the same time illustrating the serious rule of law shortcomings at the domestic level. Although the two examples below focus on Hungary, it must be stressed thatunsurprisingly-Central and Eastern European EU Member States have been making up the bulk of intra-EU BIT disputes-pre- and post-Achmea. ${ }^{41}$

\subsection{Example number one: Magyar Farming v. Hungary}

The dispute in Magyar Farming v. Hungary arose over a Hungarian regulation which Magyar Farming, a company founded in 1997 by a group of British farmers, claimed resulted in the expropriation of its leasehold rights to 760 hectares of state-owned land in Hungary's North-Western region of Ikrény and also damaged the value of its business. Along with its Hungarian subsidiaries Kintyre and Inícia, Magyar Farming filed the claim under the UK-Hungary BIT in 2017, seeking $€ 17.9$ million in damages. ${ }^{42}$

Through Inícia, Magyar Farming held the rights to the land in dispute under a leasehold agreement which provided for a 'pre-lease' right, allowing Inícia to extend the leasehold on the same terms. In 2011, Hungary passed legislation precluding the right to exercise clauses such as the one held by Inícia. A dispute subsequently broke out when Magyar Farming argued it should be allowed to extend the lease, which was due to expire in 2014, as originally agreed. After local court proceedings, Inícia was served with an eviction notice and later that year Hungarian authorities purported to transfer possession of the land to the winners of a tender process it had held. Inícia refused to leave, which Hungary says then gave rise to 'a number of unpleasant incidents', including one occasion where Magyar Farming's managing director and founder Andrew Hunter 'physically assaulted a farmer'. Magyar Farming argues that Hungarian authorities attempted to intimidate Hunter by having him arrested without explanation and denied access to a lawyer before being released without charge the following morning.

\footnotetext{
$\overline{40}$ Cf. e.g. Sipiorski 2019; Lavranos 2008.

41 See the helpful tables listing all the pre- and post-Achmea intra-EU BIT disputes in: Gáspár-Szilágyi and Usynin 2019, at p. 61 et seq.

42 Magyar Farming Company Ltd, Kintyre Kft and Inicia Zrt v. Hungary, (ICSID Case No. ARB/17/27), Award 13 November 2019, https://www.italaw.com/sites/default/files/case-documents/italaw10914.pdf.
} 
In 2016, then-UK Prime Minister David Cameron reached a 'gentlemen's agreement' with Hungarian counterpart Viktor Orbán that Hungary would buy the land. However, Hungarian authorities later rejected the deal and Magyar Farming filed its ICSID claim the following year. The arbitral tribunal found that while Hungary could remove or alter the leasehold provisions, 'such a change should not have applied retrospectively to already vested rights' ${ }^{43}$ It found the State's actions resulted in the expropriation of Inícia's rights under the lease and that there was "no rationale' to justify Hungary not paying compensation. ${ }^{44}$ Accordingly, the arbitral tribunal awarded Magyar Farming $€ 7.1$ million in compensation plus interest at the rate of 6-month EURIBOR + $2 \%$ compounded semi-annually, dating from 2015 until payment. It further awarded Magyar Farming around US\$700,000 for the arbitration costs and legal fees. ${ }^{45}$

Before reaching its conclusion on the merits by finding that Hungary breached its obligations under the UK-Hungary BIT, the arbitral tribunal dismissed the Achmeaobjections raised by Hungary. More specifically, Hungary raised two jurisdictional objections. First, that its consent to arbitrate contained in the BIT had been rendered inapplicable by its accession to the EU in 2004, and, second, that the CJEU's Achmea judgment is binding on the tribunal. Hungary argued that the BIT's dispute resolution clause was incompatible with EU law following the Achmea decision. Where there was a conflict between the BIT and EU law, such as whether it consented to arbitrate intra-EU BIT claims, it was EU law that prevailed, according to Hungary.

In contrast, Magyar Farming argued that the BIT contained a valid offer to arbitrate when it filed its request for arbitration in 2017 - and that in any event EU Treaties do not prevail over the BIT.

Moreover, Magyar Farming argued that the Achmea decision was not binding on the tribunal, which should conduct an independent inquiry into its jurisdiction under the ICSID Convention. As numerous tribunals have made clear, this inquiry should be conducted under public international law and not exclusively EU law, it said. Indeed, Magyar Farming argued that EU law does not prevail over the BIT, citing awards issued by tribunals which have made the point that the subject matter of investment treaties is different to the EU Treaties.

The arbitral tribunal sided with Magyar Farming by stating that it was "not convinced' that it was bound by the Achmea decision, noting that when Hungary and the UK agreed to sign the ICSID Convention they agreed that any arbitral tribunal constituted under it 'shall be the judge of its own competence. ${ }^{46}$ In the exercise of such power, the tribunal concluded that the tribunal itself and other panels must analyse whether there is a valid consent to arbitrate under the ICSID Convention and that it cannot 'abandon this mandate and blindly follow the determination of another adjudicatory body. ${ }^{47}$ The tribunal found that in order to determine whether

\footnotetext{
43 Ibid., para. 362.

44 Ibid., para. 367.

45 Ibid., para. 441.

46 Ibid., para. 207

47 Ibid., para. 208
} 
the dispute resolution clause in the BIT was precluded by EU law, it did not suffice to interpret EU law alone-the interpretation of both BITs and EU law was required. Not only does the CJEU have no exclusive authority to answer those questions, it 'did not even purport to address them' in the Achmea decision, ${ }^{48}$ where even a 'cursory review' of the decision revealed the court did not undertake a conflicts analysis under the Vienna Convention on the Law of Treaties. ${ }^{49}$

Moreover, even if the tribunal 'were willing to pay deference to the CJEU's reasoning,' the Achmea decision gives no guidance on issues that must be resolved to determine whether the EU Treaties preclude the application of intra-EU BITs as a matter of international law, it said. ${ }^{50}$ Notably, while the tribunal took note of the political Declarations made in January by 23 EU Member States, including the UK and Hungary, in which they affirmed that all intra-EU BITs are contrary to EU law and therefore inapplicable, it concluded that this was not the 'proper procedure' to terminate or amend the relevant BITs. ${ }^{51}$ More importantly and as argued in this article, the tribunal stressed that even if those political Declarations were regarded as an agreement to terminate the relevant BITs, the tribunal said that the consent of both parties to arbitrate in this case would not be 'retroactively invalidated'. ${ }^{2}$ Revealingly, the tribunal also noted that prior to the Achmea decision, Hungary had participated in the arbitration without objecting that its consent to arbitrate had been extinguished through its accession to the EU. ${ }^{53}$

The arbitral tribunal in Magyar Farming thus saw no reason to 'diverge from the consistent line of investment awards' that found that EU Treaties and the BIT did not share the same subject matter. ${ }^{54}$ Even if they did, there was not a conflict between the two that would preclude the BIT's consent to arbitrate. ${ }^{55}$

\subsection{Example number two: UP and C.D. Holding Internationale v. Hungary}

This dispute related to certain legal and tax reforms that impacted the claimants' fringe voucher business in Hungary. The business consists of selling vouchers to employers who grant them to employees as part of their compensation. The employees are entitled to use the vouchers at various affiliates to purchase goods and services.

The French investors entered the Hungarian market through their wholly owned subsidiary Le Chèque Déjeuner Kft (CD Hungary) in 1996 and were primarily active in the food voucher business, including both 'cold food' vouchers for use

\footnotetext{
48 Ibid., para. 210.

49 Ibid.

50 Ibid.

51 Ibid., para. 222.

52 Ibid., para. 214.

53 Ibid., para. 217.

54 Ibid., para. 236.

55 Ibid., para. 242: 'Bearing these explanations in mind, the Tribunal fails to see a conflict between Article 8 of the BIT and Articles 267 and 344 of the TFEU.'.
} 
at supermarkets and grocery stores and 'hot food' vouchers for use at restaurants. In 2011, Hungary created two types of fringe benefits vouchers: (1) SZÉP cards, a dematerialized alternative to paper vouchers, which could be used for various goods, including 'hot food', and (2) Erzsébet vouchers, which could be used to pay for 'cold food' (and eventually also 'hot food'). The investors did not meet the legal conditions to issue SZÉP cards. The Erzsébet vouchers could only be issued by Magyar Nemzeti Üdülési Alapítvány (MNUA), a government entity.

According to the claimants, SZÉP cards and Erzsébet vouchers benefited from lower tax rates vis-à-vis the vouchers issued by the investors, which made their vouchers unattractive for employers. Consequently, CD Hungary's market share and revenues fell, and it had to cease its operations in 2013. In late 2013, the claimants initiated the arbitration proceedings, arguing that these reforms resulted in the expropriation of their investment and breached Hungary's FET obligation under the France-Hungary BIT. ${ }^{56}$

In its decision on the merits, the arbitral tribunal rejected Hungary's argument that the investors' entire claim was based on the loss of economic profitability. Instead, it concluded that their case was based on indirect expropriation of their shareholding in CD Hungary by dispossession of the shareholding's economic value. ${ }^{57}$ It further observed that the loss of shares' economic value due to a state's measures can be considered an indirect expropriation. ${ }^{58}$

In its analysis, the tribunal concluded that Hungary 'knew-and intended' that no company other than three Hungarian banks could fulfil the eligibility criteria for issuing SZÉP cards. ${ }^{59}$ It further concluded that Hungary created a tax differential in favour of SZÉP cards and Erzsébet vouchers, which disadvantaged CD Hungary. ${ }^{60}$ The tribunal found it to be unnecessary to examine whether only this tax treatment caused dispossession of claimants' investment, because the dispossession was a consequence of the package of measures by Hungary (the SZÉP card, the Erzsébet voucher and the tax advantages). Taking note of the statements made in the Hungarian Parliament, the tribunal concluded that Hungary intended to create a state monopoly and evict CD Hungary from the meal voucher market or at least knew that the effect of its reforms would be that no one would continue to buy CD Hungary's meal vouchers. ${ }^{61}$ The tribunal ultimately concluded that Hungary had dispossessed the claimants of their investments, because the reforms led to a substantial loss of CD Hungary's economic value.

Next, the tribunal examined whether the dispossession of claimants' investment was done for a lawful purpose. ${ }^{62}$ The BIT provides that a dispossession may be permitted for 'reasons of public necessity.' However, the tribunal concluded that the

\footnotetext{
56 UP and C.D Holding Internationale v. Hungary, (ICSID Case No. ARB/13/35), Award, 9 October 2018, < https://www.italaw.com/sites/default/files/case-documents/italaw10075.pdf > .

57 Ibid., para. 334.

58 Ibid., paras. 353 et seq.

59 Ibid., para. 342.

60 Ibid., para. 347.

61 Ibid., paras. 349 et seq.

62 Ibid., para. 419.
} 
goal of the reforms was aimed at keeping non-Hungarian issuers out of the Hungarian voucher market and deliberately targeted the claimants' investment and that, therefore, the dispossession of the claimants' investment was not for a public purpose. ${ }^{63}$ Accordingly, the tribunal held that Hungary breached its indirect expropriation obligations the claimants more than $€ 23$ million in compensation. ${ }^{64}$

As far as the Achmea-objection is concerned, which was raised by Hungary also in this case, the tribunal rejected Hungary's argument for essentially the same reasons as in the Magyar Farming case. ${ }^{65}$ In sum, these cases illustrate how Hungarian organs-be it judicial, administrative or executive bodies-could act in a manner that is clearly below the minimum rule of law standards that should be respected within the EU. Indeed, all this took place under the watch of the EU institutions without any objections or interferences.

The CJEU's judgment in the infringement proceedings brought by the Commission against Hungary in relation to the measures that were at issue in the Magyar Farming dispute does not call this conclusion into question, despite the fact that the CJEU:

'Declares that, by adopting Paragraph 108(1) of mező- és erdőgazdasági földek forgalmáról szóló 2013. évi CXXII. törvénnyel összefüggő egyes rendelkezésekrôl és átmeneti szabályokról szóló 2013. évi CCXII. törvény (Law No CCXII of 2013 laying down various provisions and transitional measures concerning Law No CXXII of 2013 on transactions in agricultural and forestry land) and thereby cancelling, by operation of law, the rights of usufruct over agricultural and forestry land located in Hungary that are held, directly or indirectly, by nationals of other Member States, Hungary has failed to fulfil its obligations under Article 63 TFEU in conjunction with Article 17 of the Charter of Fundamental Rights of the European Union' 66

Ultimately, the fact remains that this judgment does not result in any monetary compensation for Magyar Farming and the others who were expropriated by those measures. Neither does it guarantee that Hungary or any other EU Member State for that matter will not adopt similar measures in the future.

The abolition of intra-EU BITs is thus profoundly problematic not only due to the chosen method - a Declaration, followed by a Termination Agreement-which is not legally neat to say the least, thus evidently posing the questions of basic legality and compliance with the rule of law. As the examples above demonstrate-and numerous others could be listed - the BITs provide for protection, which is nowhere found in EU law or the national law of the Member States in question-and the situation in the backsliding Member States, such as Hungary, where both our examples originated, is particularly wanting on this count. The EU's assault on intra-EU BITs

\footnotetext{
63 Ibid., paras. 414 et seq.

64 Ibid., para. 623.

65 Ibid., paras. 200 et seq.

66 CJEU, Case C-235/17 Commission v. Hungary (Judgment of Grand Chamber), 21 May 2019, ECLI:EU:C:2019:432.
} 
is thus deeply problematic. The role of the Court of Justice in this is almost incomprehensible, as building a fictitious vertically-integrated judiciary in the EU, which would include the countries which lack independent and impartial courts, is given absolute priority over the protection of the rights of investors as set out in the BITs.

\section{The court's assault on intra-EU BITs}

The Court's assault on intra-EU BITs is set out when it states in unambiguously strong language in Achmea:

'[...] according to settled case-law of the Court, an international agreement cannot affect the allocation of powers fixed by the Treaties or, consequently, the autonomy of the EU legal system, observance of which is ensured by the Court. That principle is enshrined in particular in Article 344 TFEU, under which the Member States undertake not to submit a dispute concerning the interpretation or application of the Treaties to any method of settlement other than those provided for in the Treaties (Opinion 2/13 (Accession of the EU to the ECHR) of 18 December 2014, EU:C:2014:2454, paragraph 201 and the case-law cited). ${ }^{67}$

In the subsequent paragraphs, the Court repeatedly refers to the much-criticised Opinion 2/13, where the Court opted to give absolute priority to the procedural principles related to the special nature and supremacy of the EU legal order over the substantive guarantees of human rights protection, opening the doors to a huge wave of very well informed scholarly criticism form the most illustrious commentators. ${ }^{68}$

While armed with great assertions related to EU values and many a reference to one of its most criticised and arguably least convincing Opinions in the Court's history-Opinion 2/13-, the Court of Justice does not actually 'do the math'. Indeed, 'a detailed analysis - comparable to the one in Opinion 2/13 - of how the [Court] meets [the outlined] conditions is lacking.' (Gáspár-Szilágyi 2018, at p. 363). If, agreeing with Joxerramon Bengoetxea, the CJEU frequently displays 'reasoning from consequences' (Bengoetxea 2011), Achmea could be styled as consequences without even such reasoning: we are in the realm of proclamations. The judgment is thus no different, essentially, from Opinion 2/13, as the Court, having engaged with none of the arguments in a truly brilliant Opinion of AG Wathelet, proceeds to deploy procedural considerations related to the nature of the EU legal order as re-formulated in Opinion 2/13 and, importantly, Portuguese Judges, ${ }^{69}$ in order to outlaw BITs between the Member States.

This is done in a deeply problematic way, which potentially significantly undermines the protection of the rights of Northern and Western European investors in the

\footnotetext{
67 CJEU, Achmea, para. 32.

68 E.g. de Witte and Imamović 2015; Spaventa 2015; Eeckhout 2015; see also: Kochenov 2019a, b.

${ }^{69}$ CJEU, Case C-64/16, Portuguese Judges, ECLI:EU:C:2018:117.
} 
Southern and Central and Eastern Member States of the EU-to say nothing about the Swedish investments into the German nuclear energy sector.

The official reasons behind Achmea is to protect the Member States' courts acting in their EU capacity and the proper functioning of EU law, including the principle of mutual trust, which, as the Court expressly stated in para. 58 of the judgment, are both called into question by intra-EU BITs. The actual results achieved are radically different at least at two levels discussed further below.

Moreover, the reasons listed were also entirely unnecessary, for the goals the Achmea Court claims to achieve, since investors have been successful in only ten cases over several decades out of 62 brought based on intra-EU BITs at the moment Achmea was heard ${ }^{70}$ : clearly, the Achmea judgment is a sledgehammer deployed against the nut of ten cases of potential fragmentation of EU law, which thus only exists in the Court's imagination, leaving Achmea as a purely ideological restatement of the Court's seemingly unlimited ambition no matter the facts on the ground.

Not surprisingly, such ideological restatements failing to engage with the facts failed to convince the tribunals themselves. So at the most practical level in the context of the functioning of the BITs, so far all intra-EU BIT and intra-EU ECT arbitral tribunals have refused to give prominence to Achmea-based objections brought by respondent states. ${ }^{71}$ While it may be argued that these arbitral tribunals have an intrinsic interest in accepting their jurisdiction despite the Achmea judgment, many arbitral tribunals have convincingly explained with considerable amount of effort the reasons why the Achmea judgment cannot affect their jurisdiction as long as those BITs are not formally terminated and as long as any sunset clause is still applicable. $^{72}$

This is an outcome that the CJEU could very well have predicted, given that the arbitrators are not at all bound by its idea of the scope of EU law, and conflict of law rules, ${ }^{73}$ let alone the fact that EU law is immune to the protection of the many

\footnotetext{
70 Opinion of AG Wathelet, para. 44: 'The systemic risk which, according to the Commission, intra-EU BITs represent to the uniformity and effectiveness of EU law is greatly exaggerated'. For an opposing general position, see, Szpunar 2017.

71 See for example the recent intra-EU BIT decisions in: Addiko Bank AG v. Croatia, ICSID Case No. ARB/17/37, Decision on Croatia's Jurisdictional Objection Related to the Alleged Incompatibility of the BIT with the EU Acquis, 12 June 2020 (online) Available at:https://www.italaw.com/sites/default/ files/case-documents/italaw11546.pdf; Strabag SE et al. v. Poland, ICSID case no. ADHOC/15/1, Partial Award on Jurisdiction, 2 March 2020 (online) Available at: http://icsidfiles.worldbank.org/icsid/ICSID BLOBS/OnlineAwards/C8973/DS14872_En.pdf.

Regarding intra-EU ECT cases, the Vattenfall $v$. Germany award is the most extensive analysis in which it comprehensively explains why the Achmea judgment has no bearing on intra-EU ECT disputes, Vattenfall et al. v. Germany, ICSID Case No. ARB/12/12, Decision on the Achmea issue, 31 August 2018 (online) Available at: < https://www.italaw.com/sites/default/files/case-documents/italaw9916.pdf > ..

72 See most recently regarding an intra-EU ECT dispute, Freif Eurowind v. Spain, Final Award, 8 March 2021, paras. 309 ff., https://files.lbr.cloud/public/2021-03/FREIF\%20Eurowind\%20Holdings\% 20Ltd\%20v\%20Kingdom\%20of\%20Spain\%20award_0.pdf?IkK_Bt1A46YVtc515AL1CjDipjqwa6Wp=. Regarding an intra-EU BIT dispute, the ad hoc ICSID Annulment Committee in the Edenred v. Hungary case rejected Hungary's claim that the arbitral tribunal's refusal to consider the Achmea judgment constituted a manifest excess of powers. See, Perry and Ballantyne 2020.

73 Damjanović and Quirico 2019, at pp. 123, 124 and 128, 129; Đajić 2018.
} 
substantive rights of investors guaranteed by the BITs-precisely the rights the investment tribunals are convened to protect and uphold. ${ }^{74}$

Problems can arise, of course, at the level of enforcement, especially given the astonishing stance the European Commission takes on this count, as we have seen in Micula, where the treatment of the enforcement of the award as illegal state aid by the European Commission put the losing Member State in the impossible position of either violating its international investment treaty obligations or its EU law obligations, only to see the enforcement proceedings pop-up in the $\mathrm{US}^{75}$ and the UK. ${ }^{76}$ Indeed, the Micula case illustrates that the enforcement of arbitral awards often takes place outside of the EU. In fact, despite the war waged by the European Commission and the CJEU against intra-EU BITs awards, it is thus still possible to enforce such awards in for example US courts-and post-Brexit UK courts-simply because they will care little about the CJEU's inflated ego, strictly following international law instead. Consequently, as long as some intra-EU BITs are in operation, Achmea's success is thus not obvious: it will simply be construed in the narrowest possible sense, confined to one dispute and one BIT — a reading superbly explained and justified by Csongor István Nagy (Nagy 2018).

At the level of achieving the stated goal expressed by the Court- that of reinforcing mutual trust, the case is a double failure. Firstly, like with the Opinion 2/13, the formalistic cursory reasoning of the Court ignores the fact that, in substance, EU law does not actually provide the same level of protection of substantive rights as the BITs, thus undermining investments in the internal market. Secondly, and looking at the procedural side this time, the Court's proclamation of the existing ground for mutual trust is akin to the glorification of Brezhnev's 'actually existing Socialism'-which the Central and Eastern European Commentators were the first to see: the Court fails to mention that in the context of the deterioration of the independence of the judiciary and the quality of the rule of law in a number of EU Member States, the Union does not boast too many ways to actually ensure the substantive good functioning of the judiciaries and state machineries in question (Kochenov 2017). Indeed, in its very first Rule of Law report just published, the European Commission admits exactly that. ${ }^{77}$

The result of the Court's and the Commission's war on the intra-EU BIT's is quite clear-and is also much more disturbing as a direct follow-up of this clarity: Achmea enforces the proclamation of trust and does nothing to help achieve high levels of investment protection across the Member States to ensure that the thinking underpinning the trust proclaimed actually reflects, even minimally, the reality on the ground.

\footnotetext{
${ }_{74}$ Uzelac 2019, at pp. 14-16; Nagy 2018; Damjanović and Quirico 2019, at pp. 136-154.

75 Nagy 2018, at note 14 in p. 985. See also Đajić 2018, at p. at 504 and 505; Ilie and Seow 2017.

${ }^{76}$ UK Supreme Court, Micula and others (Respondents/Cross-Appellants) v. Romania, Judgment of 19 February 2020, [2020] UKSC 5<https://www.supremecourt.uk/cases/docs/uksc-2018-0177-judgment. pdf $>$.

77 Communication from the Commission, '2020 Rule of Law report: The rule of law situation in the European Union', $\operatorname{COM}(2020) 580$ final, 30.9.2020, <https://ec.europa.eu/info/sites/info/files/commu nication_2020_rule_of_law_report_en.pdf > .
} 
It thus helps the autocrats supplying yet another rhetorical pirouette for the justification of the rule of law backsliding: 'the EU trusts us and our kangaroo courts as well'. Given that the intra-EU BITs are precisely designed to offer protection in the new Member States of Central and Eastern Europe-as we explain in detail below - this amounts to buying the autocrats more time to rig their justice systems even more without any pressure, be it money, or be it prestige, from the investment arbitration tribunals. Achmea, quite clearly, undermines the level of the rule of law protection in the EU, thus indirectly breaking the promise of Article 2 TEU without, as AG Wathelet was abundantly clear about, any clear necessity for doing so. The Court does this, quite remarkably, with a direct reference to Article 2 TEU as well as Article 19(1) TEU, which gave rise to an astonishing line of case-law aimed at protecting, not undermining the rule of law as discussed above throughout this contribution.

What is even worse, as rightly underlined by Maria Fanou, the breadth of the sweeping statement by the Grand Chamber in Achmea that the very conclusion of the BITs somehow undermines mutual trust might harbour a suspicion concerning any alternative dispute resolution systems bypassing the Courts in the sense of Article 19(1) TEU (Fanou 2019, at p. 329). This happens of course in a situation when Article 7(1) TEU has been activated against two (!) Member States (Kochenov and Pech 2016) and the independence of the judiciary in several of the members of the Union is thus brought into question.

The context of the general deterioration of the rule of law in the EU and precisely of the courts in the sense of Article 19(1), the jurisdiction of which the CJEU is protecting, is thus not quite what could possibly justify the Court's outright absurd perspective: of course BITs do not rely on mutual trust and this is precisely why the European Commission explicitly stimulated all the new Member States-to-be-for example in provisions contained in the European Agreements-to conclude BITs prior to their accession to the EU. ${ }^{78}$ Not relying on trust, when trust is unjustifiable, is the only way to make sure that cross-border investments flow undisturbedit is thus crucial to offer effective investment protection as offered by the intra-EU BITs. Taking into account these developments, it seems that the very idea of 'mutual trust' has dramatically changed over the course of the last decade: from a substantive principle it became a mere proclamation implying zero rights, thus demonstrating a line of development opposite to the evolution of the principle of judicial independence over the same time. There seems to be a general problem of a lot of the CJEU's mutual trust case-law, however blind (Anagnostas 2016), despite the fact the Court's more recent jurisprudence on the mutual trust principle since its Aranyosi and Căldăraru decision indicates that the Court has been willing to accept exceptions to the mutual trust principle, if a demanding test has been met. ${ }^{79}$

\footnotetext{
78 See note 20 for the relevant Europe Agreement provisions.

79 See Martufi and Gigengack 2020.
} 


\section{The fading of the 'mutual trust' principle}

To illustrate the statements above, it is appropriate to recall the origins of the very BITs the Court has so successfully fought against in Achmea: the treaties were nothing less than a de facto pre-accession requirement for the Member States-to-be in order to join the EU and thus formed a notable part of the 'Failure of Conditionality' exercise - as one of us described it (Kochenov 2008)—which successfully concluded the big bang enlargement process and brought Poland and Hungary, among many other Member States, in the EU, following probably the most intrusive and seemingly meticulous vetting of any new-comers' legal-political systems in the history of international law, not limited by the scope of the principle of conferral (Kochenov 2008, at pp. 80-83, and, De Ridder and Kochenov 2011). Conclusion of BITs with EU Member States was expressly stimulated in the Europe Agreements with the (then) candidate countries including Hungary ${ }^{80}$ and Poland. ${ }^{81}$ The main goal of BITs, as has been abundantly underlined in the literature, was directly related to the export of the rule of law and democracy to offset the unreliable justice systems of the countries in transition: it is in this capacity that they enter the stage of the Europe Agreements and, indirectly, the Copenhagen Criteria (Inglis 2000; Kochenov 2004; Hillion 2004; Maresceau 2006). The same logic underpinning the BITs is observable in the US and in the EU alike. ${ }^{82}$

There was of course a second goal: to protect Western investments in the world at large. Scholars are seemingly right to observe that none of the Northern and Western Member States expected to become a respondent under the BITs. ${ }^{83}$ The statistics cited by the AG in Achmea is extremely telling in this respect too, just like the interventions before the Court: all the Central and Eastern as well as Southern European Member States - the usual respondents under the BITs, where BITs thus play a vital role in protecting investors' rights, claimed that the BITs were contrary to EU law, without, nevertheless, renouncing them, as the AG informs us. ${ }^{84}$

As BITs protect Western money, thus ensuring that mutual trust is founded on substance and making a contribution to the success of the internal market, the BITs are also active at a radically different level in substance compared with ordinary EU acquis. ${ }^{85}$ As mentioned above, the substantive rights protected in the BITs are not at all mirrored in EU law and the literature is unanimous on this-but also in terms of procedural rights, by offering an option to seize an ad hoc international, independent, arbitral tribunal in a context where the level of local execution of justice can be truly pitiful, to say the least.

\footnotetext{
80 Art. 72(2)(1) Europe Agreement with Hungary (16 December 1991) OJ 1993 L347.

81 Art. 73(2)(1) Europe Agreement with Poland (16 December 1991) OJ 1993 L348.

82 Vandevelde 1993. Cf. Garro 2011; Schneider 2014, at p. 4.

83 The picture has now changed with Vattenfall, where the respondent is Germany: Damjanović and Quirico 2019

84 Paras 34-37 of the Opinion.

85 See para. 180 of the Opinion. Cf. Nagy 2018, at p. 997 et seq. (explaining, in full agreement with AG Wathelet's Opinion, that the BITs regulate issues that EU law does not address).
} 
Consequently, the Court has been out to kill the EU's own baby, bringing about both the annihilation of substantive rights and deep procedural uncertainties in terms of the quality of justice systems involved, all in the name of a proclamation of the mutual trust and the protection of the dialogue between the courts in the Union, while waging a war against international law. Panos Koutrakos is right in stating that 'the Court's approach in this case is formalistic, inward looking and hostile towards harmonious co-existence between EU and international law' (Koutrakos 2019).

Let us restate this once again: the very courts, whose jurisdiction Achmea is out to half-heartedly protect (while dealing, in essence, with the CJEU's own jurisdiction of course ${ }^{86}$ ) are the ones which could be failing at all levels under pressure from the autocrats in the hijacked states where democratic backsliding reigns. All in all, the Court has just killed quite a number of endangered birds with one Brezhnevian stone of pure-but no less dubious-ideology of absolute supremacy and autonomy of EU law, at the expense of the quality of justice in Europe and the very idea of safeguarding the rule of law and the protection of substantive rights. To agree with Panos Koutrakos' poignant assessment, 'the judgment in Achmea illustrates the most orthodox reading of the orthodoxy of EU law' (Koutrakos 2019, at p. 51) Opinion 2/13 does not stand alone anymore and has its progeny.

\section{Conclusions}

As clearly emerges from the above, Achmea, ironically, imported the 'Copenhagen dilemma' into the sphere of the protection of investors' rights, which was not suffering from it, since all the BITs concluded as part of the pre-accession exercise remained in force and operated well, precisely, to protect the rights of investors also after the accession of Central and Eastern European Member States to the European Union.

The Treaties of Accession-mute on the matter-nevertheless made it quite clear-as AG Wathelet has underlined-that the BITs were not concluded for the pre-accession period alone, which was the unconvincing argument the Commission made: not a single clause in the Accession Treaty packages demanded the BIT's renunciation. ${ }^{87}$ In fact, all intra-EU BITs have long periods of application ranging from 10 to 20 years, coupled with automatic extension periods ranging from 5 to 20 years. $^{88}$

\footnotetext{
$\overline{86}$ Ibid., at p. 53, with a reference to de Witte 2010.

87 Para 41 of the Opinion.

88 See for example, the Netherlands-Bulgaria BIT (1999):

Article 14 Entry into Force, Duration and Termination of the Agreement.
}

(1) The present Agreement shall enter into force on the first day of the second month following the date on which the Contracting Parties have notified each other in writing that their constitutionally required procedures have been complied with, and shall remain in force for a period of fifteen years.

(2) Unless notice of denunciation has been given by either Contracting Party at least six months before the date of the expiry of its validity, the present Agreement shall be extended tacitly for periods of ten years, whereby each Contracting Party reserves the right to denounce the Agreement upon notice of at least six months before the date of expiry of the current period of validity. 
Indeed, one of the goals of those BITs was to promote the rule of law in the region by making sure that the deficiencies of the local justice systems would not impair cross-border investments in the enlarged internal market. Achmea, which targets such protections came about precisely when the deficiencies in the context of judicial independence and the rule of law in some of the new Member States became crystal clear. Worse still: it directly builds on Portuguese Judges, ${ }^{89}$ the key case which allowed the Court to start attempting a push back against such deficiencies poisoning EU values, with the sole difference that the Achmea Court uses Portuguese Judges to the opposite effect: in the fight for the rule of law the proud Court of Justice does not need international allies. De Wittean selfishness of the Court is thus above all: autonomy of EU law is proclaimed at the expense of all the other interests involved, creating an unnecessary conflict with international law, stripping investors of protection and introducing the Copenhagen dilemma into the field of law, where it was not observed by design by giving strong preference to ideological proclamations over the steady development and coherent functioning of the rule of law (de Witte 2014, at p. 33). It is good news in this respect that the arbitral tribunals established under the BITs ignore Achmea en masse, chiming out awards, (GáspárSzilágyi and Usynin 2019) which protect investors against, most importantly, the lawless behaviour of the illiberal regimes, UP (formerly Le Chéque Déjeuner) and C.D. Holding Internationale v. Hungary providing the case in point in the context of Orbán-instigated expropriations. ${ }^{90}$

An alternative to the Achmea collision course that has deprived plenty of European investors of any protection in the captured 'illiberal' Member States of Central Europe was clear and simple. As has been argued in the literature and also suggested by AG Wathelet (von Papp 2013), allowing the arbitral tribunals under the BITs to refer preliminary questions was definitely an option, which could balance the grand proclamations with the actual investment protection. ${ }^{91}$ This road has not been taken and there might be no court at all in Poland and Hungary soon, which would meet the Article 267 TFEU requirements, significantly lowering the standard of protection and, ultimately, making the application of EU law-even if it does not guarantee the same level of protection as the BITs, as had been shown above-impossible.

\footnotetext{
Footnote 88 (continued)

UK-Poland BIT (1988):

Article 13 Duration and Termination.

This Agreement shall remain in force for a period of ten years. Thereafter it shall continue in force until the expiration of twelve months from the date on which either Contracting Party shall have given written notice of termination to the other. Provided that in respect of investments made whilst the Agreement is in force, its provisions shall continue in effect with respect to such investments for a period of fifteen years after the date of termination and without prejudice to the application thereafter of the rules of general international law.

89 CJEU, Case C-64/16, Portuguese Judges, ECLI:EU:C:2018:117. See for an analysis: Pech and Platon $2018 \mathrm{a}, \mathrm{b}$.

90 UP (formerly Le Chéque Déjeuner) and C.D. Holding Internationale v. Hungary, ICSID Case No. ARB/13/35 (9 October 2018), para 253.

91 See in particular: Paschalidis 2017.
} 
Open Access This article is licensed under a Creative Commons Attribution 4.0 International License, which permits use, sharing, adaptation, distribution and reproduction in any medium or format, as long as you give appropriate credit to the original author(s) and the source, provide a link to the Creative Commons licence, and indicate if changes were made. The images or other third party material in this article are included in the article's Creative Commons licence, unless indicated otherwise in a credit line to the material. If material is not included in the article's Creative Commons licence and your intended use is not permitted by statutory regulation or exceeds the permitted use, you will need to obtain permission directly from the copyright holder. To view a copy of this licence, visit http://creativecommons.org/licen ses/by/4.0/.

\section{References}

Adam S, Van Elsuwege P (2018) L'exigence d'indépendance du juge, paradigm de l'Union européenne comme union de droit. J de droit Européen 9:334

Adamski D (2019) The Social Contract of Democratic Backsliding in the 'New EU' Countries CMLRev 56: 623

Anagnostas G (2016) Mutual confidence is not blind trust! fundamental rights protection and the execution of the European arrest warrant: Aranyosi and Căldăraru. CMLRev 53:1683

Andenæs M, Contartese C (2019) EU Autonomy and investor-state dispute settlement under inter se agreements between EU member states: Achmea. CMLRev 56:157

Anderer C (2010) Bilateral investment treaties and the EU legal order: implications of the lisbon treaty. Brooklyn J Int'1 L 35:851

Bengoetxea J (2011) Reasoning from Consequences from luxembourg. In: Koch H, Hagel-Sorensen K, Haltern U and Weiler JHH (eds) Europe-The New Legal Realism: Essays in Honour of Hjalte Rasmussen. DJØF, Copenhagen

Blokker P (2019) Populist counter-constitutionalism, conservatism, and legal fundamentalism. EUConst 15:518

Bonelli M (2017) From a community of law to a union of values?' (2017) EUConst 13: 793

Brower C, Blanchard S (2014) What's in a meme? The Truth about Investor-State Arbitration: 'Why It Should Not, and Must Not, Be Repossessed by States.' Columbia J Trans L 52:704

Đajić SV (2018) The Achmea Cases-story on treaty interpretation, forum competition and international law fragmentation. Zbornik radova 52:491

Damjanović I, Quirico O (2019) Intra-EU investment dispute settlement under the energy charter treaty in light of Achmea and Vattenfall: a matter of priority. CJEL 26:102

De Ridder E, D. Kochenov D, (2011) Democratic conditionality in eastern enlargement: ambitious window dressing. Eur Foreign Aff Rev 16:589

de Witte B (2014) A Selfish Court? The Court of Justice and the Design of International Dispute Settlement beyond the European Union. in: Cremona M and Thies A (eds) The European Court of Justice and External Relations Law: Constitutional Challenges. Hart Publishing, Oxford

de Witte B, Imamović Š (2015) Opinion 2/13 on accession to the ECHR: defending the EU legal order against a foreign human rights court. ELR 40:683

Eeckhout P (2015) Opinion 2/13 on EU accession to the ECHR and judicial dialogue-autonomy or autarky. FILJ 38:955

Fanou M (2019) Intra-European union investor-state arbitration Post-Achmea: RIP? Maastricht J Eur \& Comp L 26:316

Garro A (2011) Trade and investment treaties, the rule of law, and the standards of the administration of justice. U Miami Inter-Am L Rev 42:267

Gáspár-Szilágyi S (2018) It Is not just about investor-state arbitration: a look at case C-284/16. Achmea BV European Papers 3(1):357

Gáspár-Szilágyi S, Usynin M (2019) The uneasy relationship between intra-EU investment tribunals and the Court of Justice's Achmea judgment. EILAR 4:29

Grabowska-Moroz B (2020) Understanding the Best Practices in the Area of the Rule of Law'. RECONNECT Working Paper D.8.1.

Hillion C (2004) The copenhagen criteria and their progeny. In: Hillion C (ed) EU enlargement: a legal approach. Hart Publishing, Oxford 
Ilie L, Seow A (2017) Case-note on Micula v. Romania. EILAR 2: 151

Inglis $\mathrm{K}$ (2000) The Europe agreements compared in the light of their pre-accession reorientation. CMLRev 37:1173

Kochenov D (2004) Behind the copenhagen façade. the meaning and structure of the copenhagen criterion of democracy and the rule of Law. Euro Integration Online Papers 8(1): 1

Kochenov D (2008) EU enlargement and the failure of conditionality: pre-accession conditionality in the fields of democracy and the rule of law. Kluwer Law International, The Hague

Kochenov D (2017) The EU and the rule of law-Naïveté or a grand design?. In: Adams M, Meuwese A and Hirsch Ballin E (eds) Constitutionalism and the rule of law: bridging idealism and realism. CUP, Cambridge

Kochenov D (2019b) EU law without the rule of law: is the veneration of autonomy worth it? YEL 34:74

Kochenov D (2019) Article 7: un commentaire de la fameuse disposition 'morte'. Revue des affaires européennes 33

Kochenov D (2020) Rule of law as a tool to claim supremacy. RECONNECT Working Paper No. 9.

Kochenov D, Bárd P (2019) The last soldier standing? Courts versus politicians and the rule of law crisis in the new member states of the EU. EYCL 1:243

Kochenov D, Butler G (2020) The independence and lawful composition of the court of justice of the european union: replacement of advocate general Sharpston and the Battle for the Integrity of the Institution. Jean Monnet Working Paper No. 2 (NYU Law School).

Kochenov D, Pech L (2017) Better late than never? On the commission's rule of law framework and its first activation. JCMS 54:1062

Kochenov D, de Búrca G, Williams A (eds) (2015) Europe's Justice Deficit? Hart Publishing, Oxford

Kochenov D, Magen A and Pech L (eds) (2016) The Great Rule of Law Debate in the EU. JCMS 54: 1043-1259

Koncewicz TT (2020) The supranational rule of law as first principle of the european public space—on the journey in ever closer union among the peoples of Europe in Flux. Palestra 5:167

Koutrakos P (2019) The Autonomy of EU Law and International Investment Arbitration' NJIL 88: 41

Lavranos N (2008) The solange-method as a tool for regulating competing jurisdictions among international courts and tribunals. Loy. L.A. Int'l \& Comp. L. Rev. 30: 275.

Lavranos N (2010) Protecting EU law from international law. EFARev 15:265

Lavranos N (2011) Member states' bilateral investment treaties (BITs): lost in transition? The Hague Yearbook of Int'1 L 24:281

Lavranos N (2018) After Achmea: The Need for an EU Investment Protection Regulation. (17 March) Kluwer Arbitration blog. (online) http://arbitrationblog.kluwerarbitration.com/2018/03/17/achmeaneed-eu-investmentprotection-regulation/?doing_wp_cron=1597733139.13008189201354980468 755

Lenaerts K (2019) Our judicial independence and the quest for national, supranational and transnational justice. In: Selvik G et al. The Art of Judicial Reasoning: Festschrift in Honour of Carl Baudenbacher. Springer, Cham

Mader O (2019) Enforcement of EU values as a political endeavour: constitutional pluralism and value homogeneity in times of persistent challenges to the rule of law' (2019) HJRL 11: 133

Maresceau M (2006) Quelques réflexions sur l'application des principes fondamentaux dans la stratégie d'adhésion de l'UE' in Le droit de l'Union européenne en principes: Liber amicorum en l'honneur de Jean Raux. LGDJ, Paris

Martufi A, Gigengack D (2020) Exploring mutual trust through the lens of an executing judicial authority: the practice of the Court of Amsterdam in EAW proceedings, New J Euro Criminal Law 11: 282. (online) https://journals.sagepub.com/doi/full/https://doi.org/10.1177/2032284420946105.

Mistelis L (2020) 2020 QMUL-CCIAG Survey: Investors' Perceptions of ISDS. (online) available at: http://www.arbitration.qmul.ac.uk/media/arbitration/docs/QM-CCIAG-Survey-ISDS-2020.pdf

Nagy CI (2018) Intra-EU bilateral investment treaties and EU law after Achmea: 'Know Well What Leads You Forward and What Hold You Back.' German LJ 19:981

Paschalidis P (2017) Arbitral tribunals and preliminary references to the EU Court of Justice. Arbitr Int 33:663

Paschalidis P (2020) The pressing need for a European investment court. (10 February) Global Arbitration Review. (online) https://globalarbitrationreview.com/article/1214259/the-pressing-need-for-aeuropeaninvestment-court> 
Pech L and Kochenov D (2021) Respect for the rule of law in the case-law of the court of justice of the EU. SIEPS.

Pech L, Platon S (2018) Judicial Independence under threat: the court of justice to the rescue in the ASJP Case. CMLRev 55:1836

Pech L and Platon S (2018) Rule of Law backsliding in the EU: The Court of Justice to the rescue? Some thoughts on the ECJ ruling in Associação Sindical dos Juízes Portugueses (13 March) EU law analysis. (online) https://eulawanalysis.blogspot.com/2018/03/rule-of-law-backsliding-in-eu-courtof.html

Pech L, Scheppele KL (2017) Illiberalism within: rule of law backsliding in the EU. CYELS 19:3

Perry S and Ballantyne J (2020) Hungary fails to reopen intra-EU BIT awards, Global Arbitration Review, 18 March 2020, at https://globalarbitrationreview.com/achmea/hunga ry-fails-reopen-intra-eu-bit-awards.

Rizcallah C and Davio V (2020) 'L'article 19 du Traité sur l'Union européenne: sésame de l'Union de droit' (2020) Rev. trim. Dr. h. 122: 156

Sadowski W (2018) Protection of the rule of law in the European union through investment treaty arbitration: is judicial monopolism the right response to illiberal tendencies in Europe? CMLRev 55:1025

Sadurski W (2019) Poland's constitutional breakdown. OUP, Oxford

Sanderson C (2021) Germany settles with Vattenfall, Global Arbitration Review, 5 March 2021, at https:// globalarbitrationreview.com/germany-agrees-settle-vattenfall-case.

Scheppele KL (2017) The Social Lives of Constitutions. In: Blokker P and Thornhill C (eds), Sociological Constitutionalism. CUP, Cambridge

Scheppele KL, Kochenov D and Grabowska-Moroz B (2020) EU Values Are Law, after All: Enforcing EU Values through Systemic Infringement Actions by the European Commission and the Member States of the European Union All. YEL38: 1-121

Schneider M (2014) The Role of the State in Investor-State Arbitration: Introduction. in: Lalani S and Lazo RP (eds) The Role of the State in Investor-State Arbitration. Martinus Nijhoff, The Hague

Schout A and Luining M (2018) The missing dimension in rule of law policy From EU policies to multilevel capacity building. Clingendael Instituut Report, January 2018. (online) https://www.cling endael.org/publication/missing-dimension-rule-law-policy.

Sipiorski E (2019) Conflicting conceptions of constitutionalism: investment protection from the European union and international perspectives. Netherlands Int't L Rev 66:219

Smith M (2019) Staring into the abyss: a crisis of the rule of law in the EU. ELJ 25:563

Spaventa E (2015) A very fearful court? the protection of fundamental rights in the european union after opinion 2/13. MJECL 22:35

Stoppioni E (2020) Disentangling Clashes of Paradigms: Member States Reinstate EU Law Philosophy Terminating BITs in the Internal Market. (7 May) EU Law Live (online) https://eulawlive.com/oped-disentangling-clashes-of-paradigms-member-states-reinstate-eu-law-philosophy-terminatingisds-in-the-internal-market-by-edoardo-stoppioni/

Szpunar M (2017) Is the court of justice afraid of international jurisdictions? Polish Yearbook of International Law XXXVI I:125

Uzelac A (2019) Why Europe Should Reconsider Its Anti-Arbitration Policy in Investment Disputes. Access to Justice in Eastern Europe 6

Vandevelde K (1993) US bilateral investment treaties: the second wave. MJIL 14:621

von Papp K (2013) Clash of 'autonomous legal orders': Can EU member state courts bridge the jurisdictional divide between investment tribunals and the ECJ? a plea for direct referral from investment tribunals to the ECJ. CMLRev 50:1039

Publisher's Note Springer Nature remains neutral with regard to jurisdictional claims in published maps and institutional affiliations. 